\title{
EFFECTS OF PRE-GERMINATION TREATMENTS, SALT AND WATER STRESSES ON GERMINATION OF ACACIA EHRENBERGIANA HAYNE AND ACACIA SEYAL DEL. (MIMOSOIDEAE): TWO ALGERIAN NATIVE SPECIES
}

\author{
Ben ZETTA, H. ${ }^{*}$ - AMrANi, S. - NACER, A. \\ Laboratory of soil biology, Laboratory of Biology and Physiology of Organisms, Faculty of \\ Biological Sciences, University of Sciences and Technology Houari Boumediene BP $n^{\circ} 32 \mathrm{El}$ \\ Alia, Bab Ezzouar, 16111 Algiers, Algeria \\ *Corresponding Author \\ e-mail: benzettahanane@gmail.com \\ phone: +213-21-24-72-17; fax: +213-21-24-79-50 \\ (Received $31^{\text {st }}$ Jan 2017; accepted $2^{\text {nd }}$ Jun 2017)
}

\begin{abstract}
Acacia ehrenbergiana Hayne and Acacia seyal Del. are two desert trees of the Algerian Sahara that for a long time were confused. These two species present high potentials for desert areas rehabilitation therefore for successful seed germination and establishment three pre-germination treatments (manual scarification, boiling water and concentrated sulphuric acid) were used to overcome seeds dormancy. Once the optimal conditions are determined, we examined the effects of two abiotic stresses (salinity and water deficiency) on their seeds germination using eight levels of salinity $(0,50$, $100,150,200,250,300$ and $350 \mathrm{mM}$ of $\mathrm{NaCl})$ and six concentrations of $\mathrm{PEG}_{6000}(0,-2,-4,-6,-8$ and -10 bars) on Acacia ehrenbergiana Hayne and Acacia seyal Del. Germination rate and mean germination time were calculated and data were subjected to analysis of variance (ANOVA) followed by Newman-Keuls test. Our results show that manual scarification and sulphuric acid had significant effects on the seeds germination of Acacia ehrenbergiana Hayne meanwhile, only sulphuric acid enhanced Acacia seyal Del. seeds germination. Under salt and water stresses, the germination rate and mean germination time of Acacia ehrenbergiana Hayne were less affected than those of Acacia seyal Del. Therefore manual scarification and sulphuric acid treatments could be applied and adopted at laboratory level or even at nurseries to raise plants germination and plantations establishment for desert areas rehabilitation. Thus, Acacia ehrenbergiana Hayne seems to be more suitable for massive propagation as it demonstrates resilience when facing harsh abiotic stresses (salt and water stresses).
\end{abstract}

Keywords: Acacia trees, seeds, germination, coat dormancy, abiotic stress, desert

\section{Introduction}

Native acacia trees are frequent, widespread and emblematic species that grow in Algerian desert areas which cover $2 / 3$ of the country surface. They are represented by six species; five of them were recently transferred from the genus Acacia to the genus Vachellia: Acacia tortilis (Forssk.) Hayne subsp. raddiana (Savi) Brenan., Acacia nilotica subsp. adstringens (Schumach. \& Thonn.) Roberty, Acacia nilotica subsp. tomentosa (Benth.) Brenan, Acacia ehrenbergiana Hayne, Acacia seyal Del. and one species: Acacia laeta R.Br. ex Benth. was transferred to the genus Senegalia (Ross, 1979; Kyalangalilwa, 2013).

These species play fundamental roles in desert areas, allowing sand's fixation, helping the water infiltration and improving the redistribution of nutritive elements in the soil. Moreover, their ability to develop dual symbiosis with Rhizobia and endomycorrhizal fungi contribute to the improvement of soil fertility (Grouzis and Le Floc'h, 2003; Noureddine et al., 2010). These prominent, wide range ecological services 
providers are well adapted to the main constraints of arid and semi-arid areas (drought, high temperatures, salinity and extreme light...) therefore, they are valuable trees and good candidates to combat desertification and to integrate any restoration, rehabilitation and reforestation programs in Algeria. Indeed, they have been already included as elite species in the Great Green Wall project, a project of plantation initiated by sahelian countries to fight the desertification progress (Dia and Niang, 2010; Ba, 2010; Hannani and Chehma, 2012).

The propagation and the distribution of these species require higher germination and establishment rates. One of the obstacles of acacias seed germination is the impermeable teguments to water and oxygen causing a physical dormancy (Holmes et al., 1987). In this case, it is necessary to apply pre-germination treatments to overcome the coat dormancy. Several artificial methods have been used to break the dormancy of these seeds, including physical (manual scarification, boiling water and cold water) and chemical pre-germination treatments (sulphuric acid and organic solvents) (Hanna, 1984; Cavanagh, 1987; Côme, 1970; Mousavi et al., 2011; Aref et al., 2011).

In addition, studies of the effects of most frequent environmental stresses encountered in these areas such as salt and water stresses on germination stage are of outmost importance for regeneration and consequently successful establishment of plantations (Aref et al., 2004; Jaouadi et al., 2010).

Studies have been carried out in order to determine the effects of pre-germination treatments, salt and water stresses on acacias seed germination (Teketay, 1996; AlMudaris et al., 1999; Ndour et Danthu, 1999; Jaouadi et al., 2004; Aref et al., 2004; Jaouadi et al., 2010; Kassa et al., 2010; Abari et al., 2011).

In Algeria, few published articles focused on these species including the works of Kebbas et al. (2015) and Hannani et al. (2016) on the effects of pre-germination treatments on A. tortilis (Forssk.) Hayne subsp. raddiana (Savi) Brenan. and the studies of Karoune et al. (2013) and Kebbas et al. (2013) on the characteristics of germination under salt stress of A. albida (Del.) A. Chev. and water stress on A. tortilis (Forssk.) Hayne subsp. raddiana (Savi) Brenan. respectively. Recently, Kheloufi et al., 2016 investigated the germination behaviour and compare the levels of tolerance to salinity in three Acacia species (Acacia delbata Link., Acacia ehrenbergiana Hayne and Acacia tortilis (Forssk.) Hayne var. raddiana.

A. ehrenbergiana Hayne which is found in the North Sahel, the Southern and Central Sahara, the Arabian Peninsula and East Africa resembles the A. seyal Del. SudanoSahelian species (Benchelah et al., 2006; Contu, 2012). A. ehrenbergiana Hayne grows in dry semi-desert areas where it represents one of the most drought-tolerant species among the common African acacias occurring in the rainfall belts $50-400 \mathrm{~mm}$. In Algeria, this species can be found in Ahaggar, Tassili n'Ajjer and Tinghert Hamada while A. seyal Del. stands are rarely found in Ahaggar (Sahki and Sahki, 2004; Contu, 2012). Moreover, A. ehrenbergiana Hayne has not been mentioned in the flora dedicated to the Sahara; in Ozenda (1958) and Quezel and Santa (1962-1963); a raison of its confusion with A. seyal Del. (Celles and Maniere, 1980; Sahki and Sahki, 2004; Benchelah et al., 2006).

So, this study aims to describe seeds morphological characteristics of $A$. ehrenbergiana Hayne and A. seyal Del., two native species of the south of Algeria (Tamanrasset). Furthermore, we determined the effects of pre-germination treatments, salt and water stresses on their germination. 


\section{Material and methods}

Seeds of A. ehrenbergiana Hayne and A. seyal Del. were collected from mature pods of healthy trees in 2013 from Tamanrasset $\left(22^{\circ} 47^{\prime} 13^{\prime \prime}\right.$ North and $5^{\circ} 31^{\prime} 38^{\prime \prime}$ East) which is located in the south part of Algeria, about $2000 \mathrm{~km}$ far from the capital Algiers.

Seeds of A. ehrenbergiana Hayne were collected from Amlawlawen area about $15 \mathrm{Km}$ far from Tamanrasset city while A. seyal Del. seeds were collected from Taghemout area approximately $50 \mathrm{~km}$ far from Tamanrasset city.

In the laboratory of soil biology in 2014, the seeds were removed from their pods, damaged and insect infected seeds were discarded and the empty ones were eliminated using the floating method (Ahmadloo et al., 2011). The seeds were stored at laboratory conditions at $2-5{ }^{\circ} \mathrm{C}$ and $80 \%$ of humidity.

Seeds were evaluated with both a light microscope (ZEISS Primo Star) and a scanning electron microscope (Jeol JSM 6360LV). Their morphological characteristics: colour, shape, texture, areole shape and position, shape of the hilo-micropylar region, spermoderm brightness, seed weight refers the weight of 1,000 seeds according to ISTA (the average of 10 replicates of 100 seeds weight multiply by 10), size, volume, surface, viability and water content were evaluated (Baldwin, 1942; Justice, 1972; ISTA, 1993).

\section{Effects of pre-germination treatments on acacias seeds germination}

Seeds dormancy of acacias species is associated with seed coat impermeability to water and oxygen which constitutes in one hand an adaptive factor for their survival but in the other hand, it is an obstacle for germination even when conditions are optimal. So, in order to overcome the seeds dormancy, we performed three pre-germinations treatment, we applied Manual Scarification (MS) which consists of careful nicking or filing seed coat by hand with a nail clipper on the opposite side of the seed embryo to allow water to inter into seeds. We used Boiling Water (BW) which involves soaking the seeds in boiling water for one hour in order to soften the seed coat. And finally, soaking seeds in concentrated Sulphuric Acid (SA) $\mathrm{H}_{2} \mathrm{SO}_{4} 96 \%$ during one hour to weaken seed coat is conducted (Danthu et al., 1992; Ndour, 1997).

In order to minimize any fungal infection of the seeds during the incubation period, seeds were washed with distilled water then their surface were sterilized by immersion in ethanol $70^{\circ}$ for 30 seconds and in sodium hypochlorite solution $0.58 \%$ for one minute followed by three washes in sterilized distilled water. All these steps where done in a sterile hood.

Five replicates per treatment, with 20 seeds placed in plastic Petri dishes on filter paper were incubated in the darkness because of the seeds light insensitivity (Danthu et al., 2003) at $25^{\circ} \mathrm{C}$ (primarily experiments) and under a relative humidity of $80 \%$.

\section{Effects of salt and water stresses on acacias seeds germination}

From the results of the pre-germination treatments, optimal conditions were determined and used for further experiments. After applying the sterilization and germination protocols, salt stress effects on seeds germination at different levels of $\mathrm{NaCl}(0,50,100,150,200,250,300$ and $350 \mathrm{mM})$ were evaluated and different solutions of $\mathrm{PEG}_{6000}(0,-2,-4,-6,-8$ and -10 bars $)$ were used to induce osmotic stress (Michel and Kaufmann, 1973). 
The seeds were humidified with $\mathrm{NaCl}$ and $\mathrm{PEG}_{6000}$ solutions every $48 \mathrm{~h}$ under sterile conditions and counting the germinated seeds which was defined as the emergence of the radical was done.

\section{Determination of germination parameter}

The Germination Rate (GR) and Mean Germination Time (MGT) were determined according to Côme (1970).

$$
\mathrm{GR}=\mathrm{n} / \mathrm{N}^{*} 100
$$

Where $\mathrm{N}$ is the total number of seeds and $\mathrm{n}$ is the number of germinated seeds.

$$
\text { MGT }=\mathrm{N}_{1} \mathrm{~T}_{1}+\mathrm{N}_{2} \mathrm{~T}_{2}+\ldots .+\mathrm{N}_{\mathrm{i}} \mathrm{T}_{\mathrm{i}} / \mathrm{N}_{1}+\mathrm{N}_{2}+\ldots . \mathrm{N}_{\mathrm{i}}
$$

Where $\mathrm{N}_{1}$ is the number of germinated seeds in $T_{1}$ and $\mathrm{N}_{2}$ the number of seeds that germinated between $\mathrm{T}_{1}$ and $\mathrm{T}_{2}$.

\section{Statistical analysis}

The data was represented as mean \pm standard deviation (SD). The experiment was made as a completely randomized design with five replicates $(n=5)$ of twenty seeds of each replicate. The data were statistically treated by one-way analysis of variance (ANOVA) and the mean values were compared using Newman-Keuls test at $\mathrm{P}<0,05$ to establish the significant differences between each treatment and control.

\section{Results}

Seeds characteristics of A. ehrenbergiana Hayne and A. seyal Del.

The morphological characteristics of the two acacias species studied represented in (Table 1) and (Fig. 1) show some similarities in seeds shape, texture, areole shape and position. A. ehrenbergiana Hayne have a light brown colour while A. seyal Del. have a greenish brown colour. Morphology of the seeds varied significantly $(\mathrm{P}<0,05)$ in length, width, volume, surface and weight of 1000 seeds. The seeds showed a high viability of 90 and $95 \%$ for A. ehrenbergiana Hayne and A. seyal Del. respectively.

\section{Effects of pre-germination treatments on acacias seeds germination}

In this work, we investigated the effects of three pre-germination treatments to overcome the seeds dormancy of A. ehrenbergiana Hayne and A. seyal Del. All pregermination treatments improved the GR and MGT for both species while the control group presented very low GR (13\% for A. ehrenbergiana Hayne and $18 \%$ for A. seyal Del.) and we noticed an increase in the MGT of both species $(7,79$ days for $A$. ehrenbergiana Hayne and 6,78 days for A. seyal Del.). 
Table 1. A. ehrenbergiana Hayne and A. seyal Del. seeds morphological characteristics

\begin{tabular}{|c|c|c|c|c|c|c|c|c|c|c|c|c|c|c|c|}
\hline \multirow{2}{*}{ Species } & \multirow{2}{*}{$\begin{array}{c}\text { Seed } \\
\text { colour }\end{array}$} & \multirow{2}{*}{$\begin{array}{c}\text { Seed } \\
\text { shape }\end{array}$} & \multirow{2}{*}{$\begin{array}{c}\text { Seed } \\
\text { texture }\end{array}$} & \multirow{2}{*}{$\begin{array}{c}\text { Areole } \\
\text { shape }\end{array}$} & \multirow{2}{*}{$\begin{array}{c}\text { Areole } \\
\text { position }\end{array}$} & \multirow{2}{*}{$\begin{array}{l}\text { shape of } \\
\text { the hilo- } \\
\text { micropylar } \\
\text { region }\end{array}$} & \multirow{2}{*}{$\begin{array}{c}\text { Spermoderm } \\
\text { brightness }\end{array}$} & \multirow{2}{*}{$\begin{array}{l}\text { Weight of } \\
1000 \text { seeds } \\
\text { (g) }\end{array}$} & \multicolumn{3}{|c|}{ Seed size $(\mathbf{m m})$} & \multirow{2}{*}{ Volume $\left(\mathrm{mm}^{3}\right)$} & \multirow{2}{*}{$\begin{array}{c}\text { Surface } \\
\left(\mathbf{m m}^{2}\right)\end{array}$} & \multirow{2}{*}{$\begin{array}{c}\text { Viability } \\
(\%)\end{array}$} & \multirow{2}{*}{$\begin{array}{c}\text { Water } \\
\text { content }(\%)\end{array}$} \\
\hline & & & & & & & & & Length & Width & Thickness & & & & \\
\hline \multirow[t]{2}{*}{$\begin{array}{c}A . \\
\text { ehrenbergiana } \\
\text { Hayne }\end{array}$} & $\begin{array}{l}\text { Light } \\
\text { brown }\end{array}$ & & & & & & & $23,26 \pm 0,99^{* * *}$ & $5,67 \pm 0,66^{* * *}$ & $2,58 \pm 0,50^{* * *}$ & $1,06 \pm 0,21$ & $21,34 \pm 6,20^{* * *}$ & $36,86 \pm 7,18^{* * *}$ & $95 \pm 0,81^{*}$ & $4,45 \pm 2,26$ \\
\hline & & Oblong & Smooth & Horseshoe & Subterminal & Round & Slightly shiny & & & & & & & & \\
\hline A. seyal Del. & $\begin{array}{c}\text { Greenish } \\
\text { brown }\end{array}$ & & & & & & & $36,98 \pm 0,92^{* * *}$ & $6,86 \pm 0,65^{* * *}$ & $3,72 \pm 0,66^{* * *}$ & $1,14 \pm 0,43$ & $79,80 \pm 23,95^{* * *}$ & $88,82 \pm 17,19^{* * *}$ & $90 \pm 2,16^{*}$ & $5,37 \pm 1,75$ \\
\hline
\end{tabular}

Mean \pm standard deviation, *** very highly significantly different $(P<0,001)$, * significantly different $(P<0,05)$ using the Newman-Keuls test 

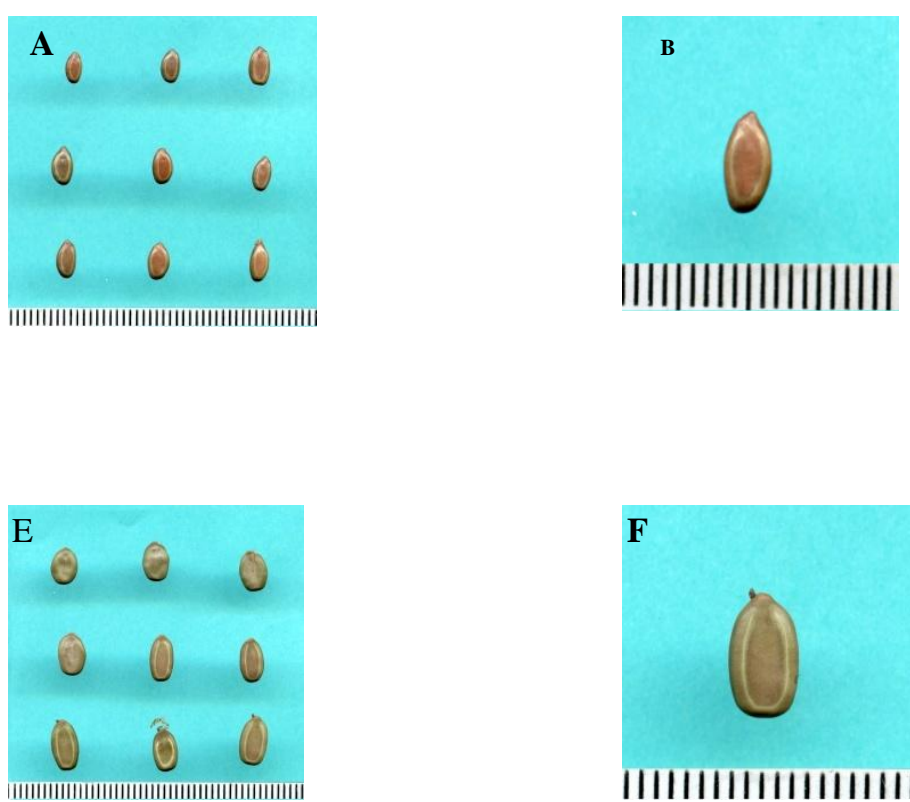
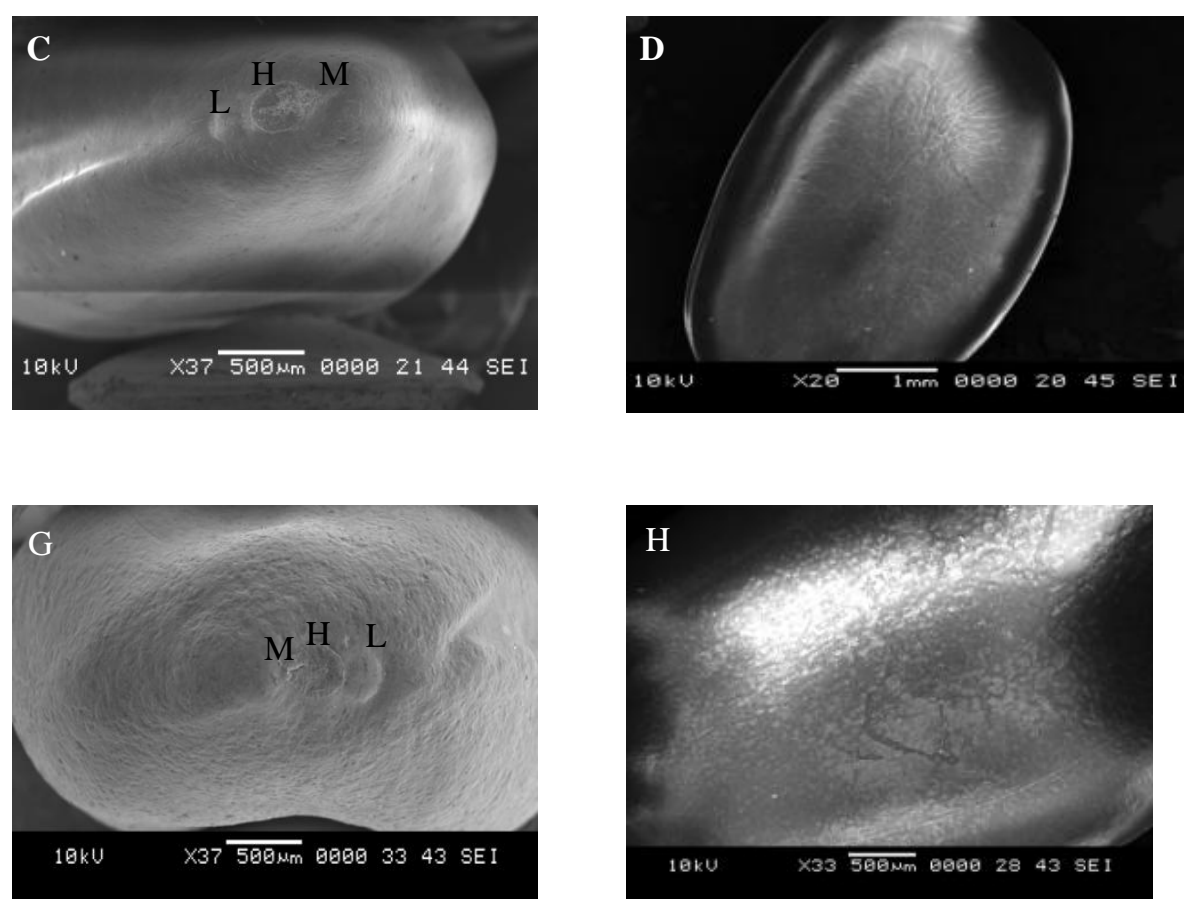

Figure 1. Light microscope and scanning electron microscope study of the seeds morphological characteristics of A. ehrenbergiana Hayne (A, B, $C$ and D) and A. seyal Del. (E, F, G and H), (L: Lens, H: Hilum and M: Micropyle) 
Using sulphuric acid and manual scarification presented high significant difference $(\mathrm{P}<0,001)$ compared to the control group with the same and the best effects on $A$. ehrenbergiana Hayne seeds germination while sulphuric acid seems to be the best pregermination treatment improving GR and MGT of A. seyal Del. Moreover, boiling water treatment came in the last position for both species giving a GR three times higher than the untreated seeds and two times lower than sulphuric acid and manual scarification (Fig. 2).

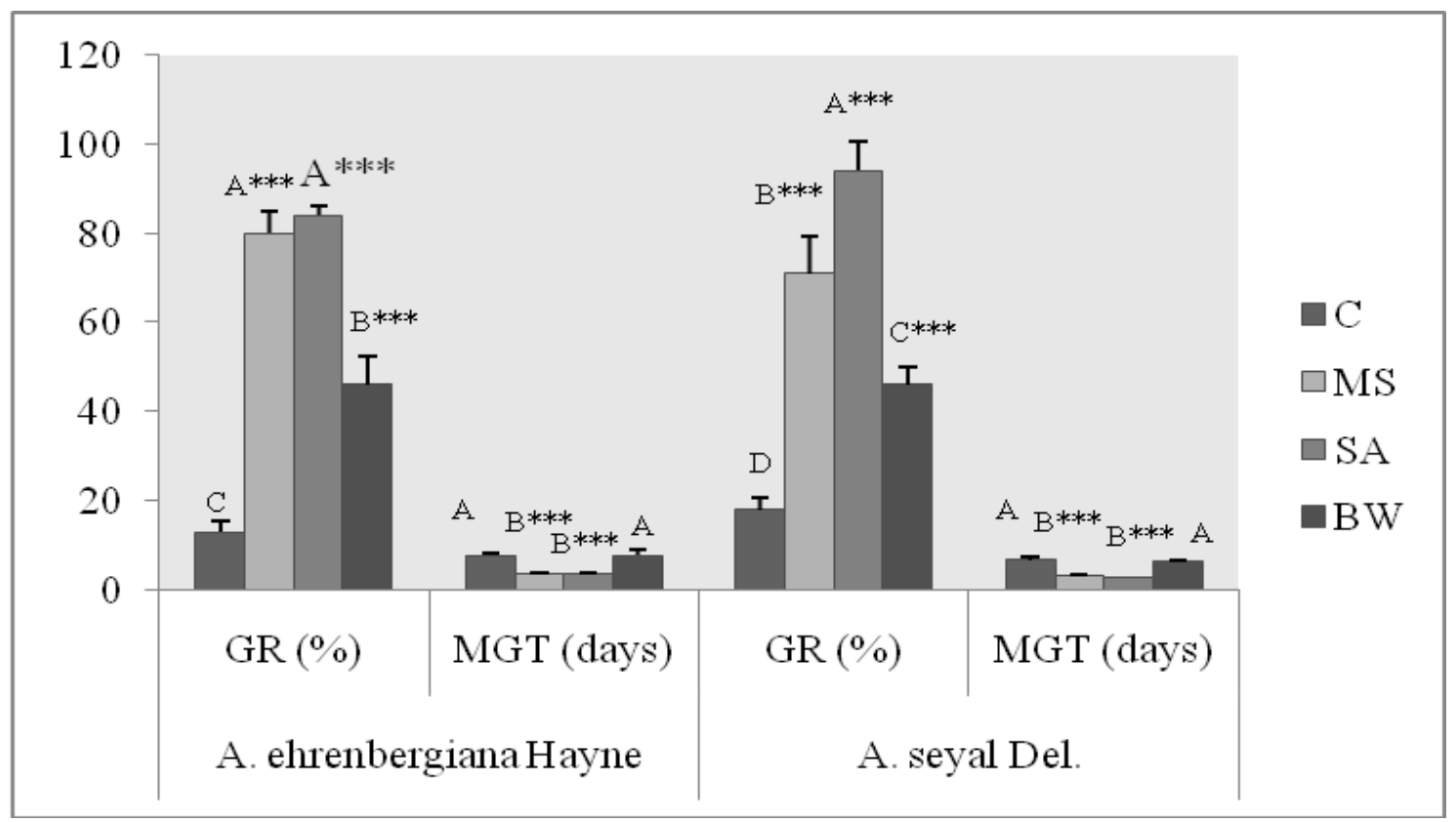

Figure 2. Effects of manual scarification, sulphuric acid and boiling water on A. ehrenbergiana Hayne and A. seyal Del. seeds germination

Germination rate (GR), Mean Germination Time (MGT), Control (C), Mechanical Scarification (MS), Sulphuric Acid (SA), Boiling Water $(B W), n=5, * * *$ Very high significant difference with the control $(P<0,001), A, B$ and $C$ statistical similarity between treatments, Means followed by the same letter are not significantly different at $P<0.05$ using the Newman-Keuls test.

\section{Effects of salt and water stresses on acacias seeds germination}

In our study, the germination behaviours under different environmental limiting conditions of salt and water stresses on germination of A. ehrenbergiana Hayne and $A$. seyal Del. were investigated.

Our results show that the highest GR and the shortest MGT occurred in the control group and we noticed an inverse correlation between GR and $\mathrm{NaCl}$ concentrations. Indeed, increasing salinity levels decreased GR and increased MGT presenting a very high significant difference $(\mathrm{P}<0,001)$ compared to control group for both species. Moreover, A. seyal Del. seems to be more sensitive than A. ehrenbergiana Hayne which germinated even at high levels of salt (at $350 \mathrm{mM}$ ) (Table 2). 
Table 2. Effects of salt stress on GR and MGT of A. ehrenbergiana Hayne and A. seyal Del. seeds germination

\begin{tabular}{|c|c|c|c|c|c|}
\hline \multicolumn{2}{|l|}{ Species } & \multicolumn{2}{|c|}{ A. ehrenbergiana Hayne } & \multicolumn{2}{|c|}{ A. seyal Del. } \\
\hline & & GR (\%) & MGT (days) & GR (\%) & MGT (days) \\
\hline \multirow[t]{2}{*}{$\mathbf{C}$} & & $77 \pm 2,73$ & $4,7 \pm 0,84$ & $82 \pm 2,73$ & $4 \pm 0,48$ \\
\hline & 50 & $63 \pm 2,73 * * *$ & $5,39 \pm 0,21$ & $68 \pm 2,73 * * *$ & $5,28 \pm 0,50 * * *$ \\
\hline \multirow{6}{*}{ 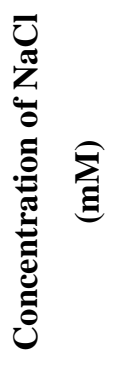 } & 100 & $52 \pm 2,73 * * *$ & $5,96 \pm 0,67 * *$ & $58 \pm 2,73 * * *$ & $5,68 \pm 0,46^{* * *}$ \\
\hline & 150 & $42 \pm 2,73 * * *$ & $8,47 \pm 0,55 * * *$ & $46 \pm 4,18 * * *$ & $6,99 \pm 0,28 * * *$ \\
\hline & 200 & $30 \pm 3,53 * * *$ & $8,91 \pm 0,25 * * *$ & $33 \pm 4,47 * * *$ & $7,52 \pm 0,70 * * *$ \\
\hline & 250 & $23 \pm 2,73 * * *$ & $9,47 \pm 1,18 * * *$ & $17 \pm 2,73 * * *$ & $9,28 \pm 0,29 * * *$ \\
\hline & 300 & $16 \pm 2,23 * * *$ & $9,63 \pm 0,24 * * *$ & $12 \pm 2,73 * * *$ & $9,76 \pm 0,22 * * *$ \\
\hline & 350 & $11 \pm 2,23 * * *$ & $10 \pm 0,00 * * *$ & $0 \pm 0,00 * * *$ & $0 \pm 0,00 * * *$ \\
\hline
\end{tabular}

Mean \pm standard deviation, Germination rate (GR), Mean Germination Time (MGT), Control (C), $n=5$, *** Very high significant difference with the control $(\mathrm{P}<0,001), * *$ high significant difference with the control $(\mathrm{P}<0,01)$ using the Newman-Keuls test

Germination assessment of $A$. ehrenbergiana Hayne and A. seyal Del. seeds under water stress was investigated using different concentrations of PEG 6000 . The different water stress levels significantly affected their seeds germination. A reduction in GR and an increased MGT were observed with very high significant difference $(\mathrm{P}<0,001)$ when compared with the control group. Thus, seeds of A. ehrenbergiana Hayne seems to tolerate high levels of water stress (-10 bars) with a GR of $21 \%$ and an MGT of 8,92 days compared to A. seyal Del. which could not germinate at -10 bars (Table 3).

Table 3. Effects of water stress on GR and MGT of A. ehrenbergiana Hayne and A. seyal Del. seeds germination

\begin{tabular}{|c|c|c|c|c|}
\hline \multirow{2}{*}{$\begin{array}{l}\text { Species } \\
\text { Concentrations of } \\
\text { PEG }_{6000} \text { (bars) }\end{array}$} & \multicolumn{2}{|c|}{ A. ehrenbergiana Hayne } & \multicolumn{2}{|c|}{ A. seyal Del. } \\
\hline & GR (\%) & MGT (days) & GR (\%) & MGT (days) \\
\hline $\mathrm{C}$ & $81 \pm 2,23$ & $4,70 \pm 0,20$ & $78 \pm 5,70$ & $3,69 \pm 0,63$ \\
\hline-2 & $71 \pm 2,23 * * *$ & $5,03 \pm 0,59$ & $61 \pm 2,23 * * *$ & $5,47 \pm 0,42 * * *$ \\
\hline-4 & $60 \pm 3,53 * * *$ & $5,54 \pm 0,59$ & $48 \pm 2,78 * * *$ & $6,12 \pm 0,67 * * *$ \\
\hline-6 & $53 \pm 2,73 * * *$ & $6,50 \pm 0,22 * * *$ & $36 \pm 2,23 * * *$ & $7,64 \pm 1,00 * * *$ \\
\hline-8 & $41 \pm 2,23 * * *$ & $7,49 \pm 0,62^{* * *}$ & $11 \pm 2,23 * * *$ & $9,33 \pm 0,62 * * *$ \\
\hline-10 & $21 \pm 2,23 * * *$ & $8,92 \pm 0,46 * * *$ & $0 \pm 0,00 * * *$ & $0 \pm 0,00 * * *$ \\
\hline
\end{tabular}

Mean \pm standard deviation, Germination rate (GR), Mean Germination Time (MGT), Control (C), $\mathrm{n}=5$, *** very high significant difference comparing with control $(\mathrm{P}<0,001)$ using the Newman-Keuls test 


\section{Discussion}

Acacia ehrenbergiana Hayne and Acacia seyal Del. are two native species to Algeria that have diverse economic and ecological significance. However, their seeds dormancy that causes low germination percentage seems to be problematic for their usage in afforestation or restoration programs.

\section{Seeds characteristics of A. ehrenbergiana Hayne and A. seyal Del.}

The seeds of A. ehrenbergiana Hayne and A. seyal Del. that were examined by both a light microscope and a scanning electron microscope presented some morphological similarities in seeds shape and texture, areole shape and position, shape of the hilomicropylar region and spermoderm brightness and some differences in colour, size, volume, surface and 1000 seeds weight.

We noticed that $A$. ehrenbergiana Hayne seeds are smaller than A. seyal Del. seeds while Al-Gohary and Mohamed (2007) found that seeds of A. seyal Del. were smaller than those of $A$. ehrenbergiana Hayne. Furthermore, in contrast of our study where we observed a light brown colour of $A$. ehrenbergiana Hayne seeds and a greenish brown colour of $A$. seyal Del. seeds, Waly (2012) reported the dark brown colour of $A$. ehrenbergiana Hayne while Al-Gohary and Mohamed (2007) reported the brown colour of $A$. ehrenbergiana Hayne and the yellowish brown of $A$. seyal Del. seeds

In our study, seeds of both species have an oblong shape while Al-Gohary and Mohamed (2007) mentioned an obovate shape for A. seyal Del. and an oblong shape for A. ehrenbergiana Hayne seeds. Due to environmental impact, genetic variations and strategies of adaptation to different environmental conditions and soil types, differences in colour and size were reported by different studies (Al-Gohary and Mohamed, 2007; Waly, 2012; Elmagboul et al., 2014).

The present investigation revealed a significant difference in 1000 seeds weight between the two studied species. In addition, similar results of 1000 seeds weight have been noticed when compared with standard Kew database for both species (26 $\mathrm{g}$ for $A$. ehrenbergiana Hayne and $42 \mathrm{~g}$ for A. seyal Del.).

The water content is a critical factor that influences seed life span and viability; thus, from the results of the water content of $A$. ehrenbergiana Hayne $(4,45 \%)$ and $A$. seyal Del. $(5,37 \%)$ we could classify these species as true orthodox seeds implying successful long term storage (Chin et al., 1989).

In the other hand, the viability of the two species was assessed by the tetrazolium test which consists on the measurement of how many seeds in a lot are alive and could develop into plants. This test show high percentages of $95 \%$ and $90 \%$ of viable seeds of $A$. ehrenbergiana Hayne and A. seyal Del. respectively indicating their good conservation. In contrast, the tetrazolium viability test conducted by Al-Hammad and Al-Ammari, 2017 revealed that most non-germinated seeds of A. ehrenbergiana (80\%) were dead.

\section{Effects of pre-germination treatments on acacias seeds germination}

Acacia seeds have a coat dormancy that acts primarily as mechanical barrier limiting water and oxygen entrance. In natural conditions, hard seed coats are broken by fire, extreme temperatures, and digestive acids in animals stomachs or by the abrasion of blowing sand (Luna et al., 2009). In laboratory and nursery conditions, artificial methods are used. According to many authors, manual scarification, sulphuric acid, hot 
water and dry heat treatments can break down the coat inhibition (Sadhu and Kaul, 1989; Danthu et al., 1992; Al-Mudaris et al. 1999; Grouzis and Le floc'h, 2003; Abari et al., 2012; Karoune et al., 2013; Rasebeka et al., 2014).

In this study, we tested three methods to overcome seed dormancy in $A$. ehrenbergiana Hayne and A. seyal Del. We revealed that manual scarification and sulphuric acid treatments are the best pre-germination treatments for A. ehrenbergiana Hayne while sulphuric acid treatment enhanced the GR of A. seyal Del. In addition, boiling water presented low germination rates for both species.

The study of Teketay (1996) revealed that manual scarification had the best effect on A. seyal Del. seeds where the germination percentage reached $100 \%$. In the other hand, Aref et al. (2011) indicated that manual scarification was the best pre-germination treatments for A. ehrenbergiana Hayne seeds where the germination percentage was 96 $\%$, followed by sulphuric acid and boiling water with the germination percentages of $94 \%$ and $69 \%$ respectively. In contrast of our findings, the work of Aref et al. (2000) show that boiling water had positive effect on $A$. seyal Del. germination percentage (34.25\%) while it has less effect on A. ehrenbergiana Hayne germination with a germination percentage of $9.35 \%$.

\section{Effects of salt and water stresses on acacias seeds germination}

Seeds germination is a complex process depending on the genetic and environmental factors. Abiotic factors, such as salt and water stresses limit plant germination and growth during early seedling stages (Mansour, 2000). Salt and water stresses affect plants in a similar way. The osmotic effect causes a deficient in water absorption that limits seed imbibition leading to a series of metabolic changes such as the reduction in seed reserves hydrolysis and their use. Salt and water stresses can completely inhibit germination and cause a reduction in plant growth (Ahmad and Bano, 1992).

The effect of salt stress on acacias seeds germination was described by several authors (Ndour and Danthu, 1999; Aref et al., 2004; Abari et al., 2011; Karoune et al., 2013) which showed that increasing salt concentrations decreased the GR of the studied acacias species. However, in all cases, the acacias species were considered as salt tolerant species and Marcar et al. (1991) indicated that acacias species differed in their salt tolerance.

Our results of germination behaviour of A. ehrenbergiana Hayne and A. seyal Del. show that both species germinated at low concentrations of $\mathrm{NaCl}(50 \mathrm{mM}$ and $100 \mathrm{mM})$ with at least $50 \%$ GR, while the GR at high concentration $(350 \mathrm{mM})$ was decreased to $11 \%$ for A. ehrenbergiana Hayne seeds and it presented a total inhibition in A. seyal Del. seeds. This might be due to the inhibition of the radical emergence as a response to water deficit and their toxic effects on the embryo (Mazher et al., 2007). Jaouadi et al. (2010) suggested that Acacia tortilis (Forsk.) Hayne ssp. raddiana (Savi) Brenan. is significantly affected by $9 \mathrm{~g} \mathrm{~L}^{-1}$ of $\mathrm{NaCl}$ giving a germination rate of $60 \%$, furthermore, this species continues to germinate even at high concentrations of $\mathrm{NaCl}$ reaching $18 \mathrm{~g} \mathrm{~L}^{-}$ ${ }^{1}$ with a germination rate of $50 \%$. In our case, A. ehrenbergiana Hayne could germinate even at high level of $\mathrm{NaCl}\left(350 \mathrm{mM}=17 \mathrm{~g} \mathrm{~L}^{-1}\right)$ however it gave a GR of $11 \%$. Also, the study conducted by Kheloufi et al. (2016) revealed that the seeds of A. ehrenbergiana Hayne collected in Oued Tin Amezzegin (Tamanrasset, Southern of Algeria) gave a final GR of $100 \%$ for the first three seawater treatments $(0,10$, and $30 \%)$ and $78 \%$ in the presence of $50 \%$ of seawater. 
The results of the effect of water stress on A. ehrenbergiana Hayne and A. seyal Del. seeds showed that GR of both species were significantly affected particularly, A. seyal Del. seeds which presented an inhibition at high level of water stress (-10 Bars). Kassa et al. (2010), reported that this species can germinate even at high level of water stress ($12 \mathrm{MPa}$ ) and asserted that it is classified as tolerant species to water stress. In addition, Ndour and Danthu (1999) reported that A. ehrenbergiana Hayne is more tolerant than $A$. seyal Del. to water stress and both species are considered as tolerate species to water stress because they germinated even at $-2,1 \mathrm{MPa}$.

Our research was lead by the lack of studies on the biology and characteristics of seeds of highly tolerant and beneficial trees in arid areas of Algeria. The present study show some important elements to distinguish between $A$. ehrenbergiana Hayne and $A$. seyal Del regarding their seeds morphological characteristics. In addition, because of their seed coat dormancy, we applied chemical and physical treatments in order to obtain rapid and synchronous germination essential for ensuring seedling establishment. We described the optimal germination conditions of these two species and established their germination behaviour under salt and water stresses two of the most frequent environmental stresses that prevail in arid areas of Algeria. These results are of a significant important as A. ehrenbergiana Hayne and A. seyal Del. two native species that present a good choice and could be suitable for land rehabilitation, restoration and afforestation programs in these areas.

Acknowledgements. The authors would like to extend their sincere appreciation for all the team of National institute of Forest Research - Station of Tamanrassat- Algeria for their help in providing the seeds of A. ehrenbergiana Hayne and A. seyal Del.

\section{REFERENCES}

[1] Abari, A. K., Nasr, M. H., Hodjati, M., Bayat, D., Radmehr, M. (2012): Maximizing seed germination in two Acacia species.- Journal of Forestry Research 23: 241-244.

[2] Abari, A. K., Nasr, M. H., Hojjati, M., Bayat, D. (2011): Salt effects on seed germination and seedling emergence of two Acacia species.- African Journal of Plant Science 5: 52-56.

[3] Ahmad, J., Bano, M. (1992): The effect of sodium chloride on physiology of cotyledons and mobilization of reserved food in Cicer arietinum.- Pakistan Journal of Botany 24: 40-48.

[4] Ahmadloo, F., Tabari, M., Behtari, B. (2011): Effect of drought stress on the germination parameters of Cupressus Seeds.- International Journal of Forest, Soil and Erosion 1: 11-17.

[5] Al-Gohary, I. H., Mohamed, A. H. (2007): Seed morphology of Acacia in Egypt and its taxonomic significance.- International Journal of Agriculture and Biology 3: 435-438.

[6] Al-Hammad, B.A., Al-Ammari, B.S. (2017): Seed viability of five wild Saudi Arabian species by germination and X-ray tests.- Saudi Journal of Biological Sciences xxx : xxx$\mathrm{xxx}$ (Article in press).

[7] Al-Mudaris, M. A., Omari, M. A., Hattar, B. I. (1999): Enhancing germinatmon of four Australian Acacia species through seed treatments overcoming coat-imposed dormancy.Der Tropenlandwirt - Journal of Agriculture in the Tropics and Subtropics 100: 147-156.

[8] Aref, I. M. (2000): Effects of pre-germination treatments and sowing depths upon germination potential of some Acacia species.- Research Bulletin 95: 5-17.

[9] Aref, I. M., Atta, H. A. E., Shahrani, T. A., Mohamed, A. I. (2011): Effects of seed pretreatment and seed source on germination of five Acacia spp.- African Journal of Biotechnology 10: 15901-15910. 
[10] Aref, I. M., El-Juhany, L. I. Elkhalifa, K. F. (2004): Effects of sodium chloride concentrations on seed germination of Acacia nilotica ssp. tomentosa and Acacia gerrardii var. najdensis.- Online Riyadh: Plant Production Department, College of Agriculture.

[11] Ba, A. T. (2010): Grande muraille verte: choix des espèces végétales.- In: Le projet majeur Africain de la grande muraille verte: concepts et mise en œuvre. Edition institut de recherche pour le développement, Paris. 31-38pp.

[12] Baldwin, H. I. (1942): Seed testing and seed certification and storage of seeds of forest trees. In: Forest tree seed of north temperate regions with special reference to North America.- Waltham, Mass. Edition, Chronica botanica Co., North America, 240p.

[13] Benchelah, A. C., Bourziane, H., Maka, M. (2006): Arbres et arbustes du Sahara voyages au coeur de leurs usages. Edition Ebis, Paris, 239p.

[14] Cavanagh, T. (1987): Germination of hard-seeded species (Order Fabales). In: Germination of Australian native plant seed.- Melbourne, Inkata Press: 58-70pp.

[15] Celles, J. C., Manière, R. (1980): Remarques sur la distribution en Afrique ord occidentale d'Acacia seyal Delile et d'Acacia ehrenbergiana Hayne.- Candollea 35: 183-200.

[16] Chin, H. F., Krishnapillay, B., Stanwood, P. C. (1989): Seed moisture: recalcitrant vs. orthodox seeds.- In Stanwood P. C., Mc Donald, M. B. (eds.) Seed Moisture. CSSA Special Publication No. 14. Crop Science Society of America, Madison, 15-22pp.

[17] Côme, D. (1970): Les obstacles à la germination.- Edition Masson and Cie, Paris. 162p.

[18] Contu, S. 2012. Acacia ehrenbergiana. The IUCN Red List of Threatened Species 2012:e.T19892054A19997854. http://dx.doi.org/10.2305/IUCN.UK.2012.RLTS.T19892054A19997854.en

[19] Danthu, P., Roussel, J., Dia, M., Sarr, A. (1992): Effect of pre-treatment on the germination of Acacia Senegal seeds.- Seed Science and Technology 20: 111-117.

[20] Danthu, P., Roussel, J., Neffati, M. (2003): La graine et la germination d'Acacia raddiana.- In: Un arbre du désert Acacia raddiana.- Edition institut de recherche pour le développement, Paris. 265-283pp.

[21] Dia, A., Niang, A. M. (2010): Le projet majeur grande muraille verte de l'Afrique: contexte, historique, approche stratégique, impacts attendus et gouvernance.- In: Le projet majeur Africain de la grande muraille verte: concepts et mise en œuvre. Edition institut de recherche pour le développement, Paris. 11-27pp.

[22] Elmagboul, A. H., Mahgoup, S., El Doma, A. (2014): Variation in seed morphometric characteristics and germination of Acacia tortilis subspecies raddiana and Acacia tortilis subsp. spirocarpa among three provenances in Sudan.- Global Journal of Bio-science and Biotechnology 3: 191-196.

[23] Grouzis, M., Le Floc'h, E. (2003): Un arbre du désert Acacia raddiana.- Edition institut de recherche pour le développement, Paris. 313p.

[24] Hanna, P.J. (1984): Anatomical features of the seed coat of Acacia kempeana (Mueller) which relate to increased germination rate induced by heat treatment.- New Phytologist 96: 23-29.

[25] Hannani, A., Bissati-Bouafia, S., Chehma, A., Moulay, S., Benbada, S. (2016): Assays of alternative pre-treatment to remove Acacia raddiana savi (Fabaceae) seed dormancy.Ponte : International Scientific Researches Journal 72: 2-9.

[26] Hannani, A., Chehma, A. (2012): Développement végétatif et longévité de l'Acacia raddiana au Sahara septentrional.- Revue des Bio Resources 2: 50-57.

[27] Holmes, P. M., Macdonald, I. A. W., Juritz, J. (1987): Effects of clearing treatment on seed banks of the alien invasive shrubs Acacia saligna and Acacia cyclops in the southern and south-western Cape. South Africa.- Journal of Applied Ecology 24: 1045-1051.

[28] ISTA. (1993): Seed Science and Technology 21-Supplement- Zurick, Switzerland.

[29] Jaouadi, W. Hamrouni, L. Hanana, M. Khouja, M. L. (2004): Analyse de la capacité germinative de quelques espèces d'acacia exotique, $247 \mathrm{p}$. 
[30] Jaouadi, W., Hamrouni, L., Souayeh, N. Khouja, M. L. (2010): Étude de la germination des graines d'Acacia tortilis sous différentes contraintes abiotiques. - Biotechnologie, Agronomie, Société et Environnement 14(4): 643-652.

[31] Justice, O. L. (1972): Essentials of seed testing.- In: Seed Biology, $3^{\text {rd }}$ Edition, Kozlowski Edition. - Academic Press New York and London. 301-370pp.

[32] Kaabeche, M., Maoli, A., Benkheira, A. (2011): Guide - habitats, flore et faune des zones arides et sahariennes d'Algérie.

[33] Karoune, S., Kechebar, M. S., Belhamra, M., Rahmoune, C. (2013): Study the germination of Acacia albida seeds under salt stress.- International Journal of Advanced Research 1: 276-283.

[34] Kassa, A., Alía, R., Tadesse, W., Valentin, P., Bravo, F. (2010): Seed germination and viability in two African Acacia species growing under different water stress levels.African Journal of Plant Science 4: 353-359.

[35] Kebbas, S., Lekehal, Z. W., Aid, F. (2015): Analyze of different methods of scarification and biochemical composition of Acacia tortilis subsp. raddiana seeds.- Agricultura 72: 136-140.

[36] Kebbas, S., Lutts, S., Aid, F. (2013): Contribution to study of Acacia tortilis subsp raddiana seed germination, and growth seedling under different osmotic and drought constraints.- Bulletin of the University of Agricultural Sciences \& Veterinary Medicine Cluj-Napoca. Agriculture 70: 227-234.

[37] Kheloufi, A., Chorfi, A., Mansouri, L. M. (2016): The mediterranean seawater: the impact on the germination and seedlings emergence in three Acacia species.- Journal of Biodiversity and Environmental Sciences 8, 6: 238-249.

[38] Kyalangalilwa, B., Boatwright, J.S., Daru, B.H., Maurin, O., Bank, M. (2013): Phylogenetic position and revised classification of Acacia s.l. (Fabaceae: Mimosoideae) in Africa, including new combinations in Vachellia and Senegalia.- Botanical Journal of the Linnean Society 172: 500-523.

[39] Luna, T., Wilkinson, K., Dumroese, R. K. (2009): Chapter 8: Seed germination and sowing options.- In Nursery Manual for Native Plants: A Guide for Tribal Nurseries, Volume 1: Nursery management. Agriculture handbook 730. Washington, D.C.: U.S. Department of Agriculture, Forest Service. 163-183.

[40] Mansour, M. M. F. (2000): Nitrogen containing compounds and adaptation of plants to salinity stress.- Biologia Plantarum 43: 491-500.

[41] Marcar, N. E., Dart, P., Sweeney, C. (1991): Effect of root-zone salinity on growth and chemical composition of Acacia ampliceps BR Maslin, A. auriculiformis, A. Cunn. ex Benth. and A. mangium Willd at two nitrogen levels.- New phytologist 119: 567-573.

[42] Mazher, A. M. A., ElQuesni, E. M. F., Farahat, M. M. (2007): Responses ornamental and woody trees to salinity. - World Journal of Agricultural Sciences 3: 386-395.

[43] Michel, B. E., Kaufman, R. M. (1973): The osmotic potential of polyethylene glycol 6000.- Plant physiology 51: 914-916.

[44] Mousavi, S. R., Rezaei, M. Mousavi, A. (2011): A general overview on seed dormancy and methods of breaking It.- Advances in Environmental Biology 5(10): 3333-3337.

[45] Ndour, P. (1997): Comportement de quelques espèces du genre Acacia en condition de stress hydrique et salin simulé.- DEA: Biologie végétale, Université Cheikh Anta Diop, Dakar Sénégal.

[46] Ndour, P., Danthu, P. (1999): Effects of salinity on the germination of some African acacias. L'acacia au Sénégal. Actes de la réunion thématique sur l'acacia au Sénégal.Edited by C. Campa; C. Grignon; M. Gueye and S. Hamon. Dakar, Senegal, Collected by ORSTOM, French Institute of Scientific Research for Cooperative Development, Paris, France.

[47] Noureddine, N. E., Amrani, S., Aïd, F. (2010): Statut symbiotique et souches de rhizobia associées à l'Acacia tortilis subsp. raddiana [Acacia raddiana ss], mimosoïdée des régions désertiques de l'Algérie. - Botany 88: 39-53. 
[48] Ozenda, P. (1958): Flore du Sahara septentrional et central. - Edition CNRS, Paris, 485p.

[49] Quezel, P. Santa, S. (1962, 1963): Nouvelle Flore d'Algérie et des Régions Désertiques Méridionales. 2 Tomes. - Edition CNRS, Paris, 1170p.

[50] Rasebeka, L., Mathowa, T. and Mojeremane, W. (2014): Effect of seed pre-sowing treatment on germination of three Acacia species indigenous to Botswana.- International Journal of Plant and Soil Science $3: 62-70$.

[51] Ross, J. H. (1979): A conspectus of the African Acacia species.- Botanical Research Institute, republic of South Africa, 170p.

[52] Sadhu, R. N., Kaul, V. (1989): Seed-coat dormancy in Robinia pseudo-acacia.- Indian Forester 115: 483-487.

[53] Sahki, A., Sahki, B. R. (2004): Le Hoggar promenade botanique. Edition Atelier Espone. Lyon, 311p.

[54] Teketay, D. (1996): Germination ecology of twelve indigenous and eight exotic multipurpose leguminous species from Ethiopia.- Forest Ecology and Management 80: 209-223.

[55] Waly, N. M., Al-Zahrani, H. S., Felemban, W. F. (2012): Taxonomical studies of some Acacia seeds growing in Saudi Arabia.- Journal of American Science 8: 264-275. 